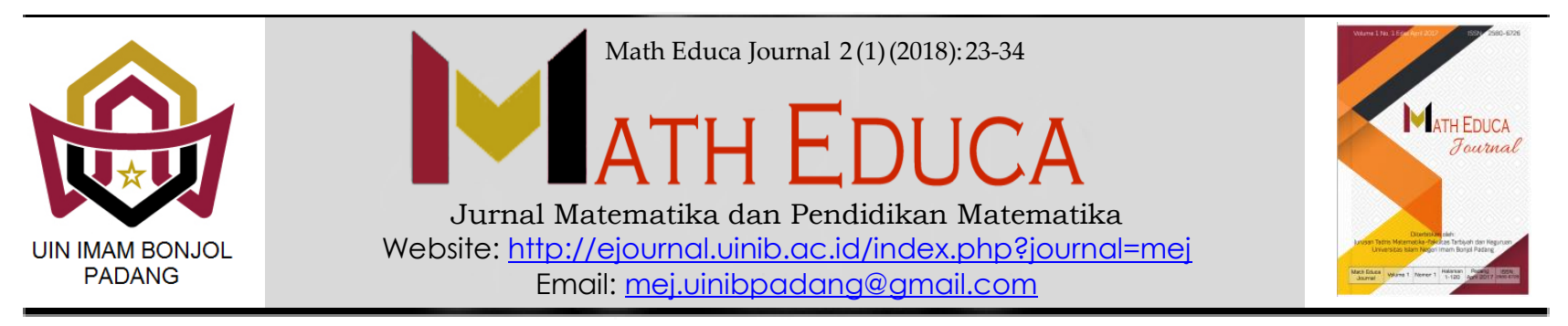

\title{
PENINGKATAN PEMAHAMAN KONSEP DAN KEMAMPUAN PENALARAN MATEMATIKA SETELAH MENGGUNAKAN PERANGKAT PEMBELAJARAN MATEMATIKA BERBASIS DISCOVERY LEARNING PADA KELAS X SMA
}

\author{
Nita Putri Utami \\ Tadris Matematika, Fakultas Tarbiyah dan Keguruan, Universitas Islam Negeri Imam Bonjol Padang \\ Email: nitautami030492@yahoo.com
}

Received: January 2018; Accepted: March 2018; Published: April 2018

\begin{abstract}
Abstrak
Pemahaman konsep dan kemampuan penalaran matematika peserta didik di sekolah-sekolah belum berkembang secara optimal. Hal ini disebabkan, guru belum menfasilitasi peserta didik untuk aktif dalam pembelajaran. Dengan kata lain pembelajaran yang terlaksana di sekolah belum pembelajaran bermakna. Salah satu penyebabnya yaitu perangkat pembelajaran matematika yang digunakan pendidik belum mendukung tercapainya tujuan pembelajaran secara optimal. Tujuan penelitian ini adalah menghasilkan perangkat pembelajaran matematika berbasis discovery learning pada materi persamaan dan pertidaksamaan linear yang valid, praktis, dan efektif. Penelitian ini merupakan penelitian pengembangan dengan menggunakan model pengembangan Plomp yang terdiri atas fase investigasi awal, fase pengembangan atau pembuatan prototipe, dan fase penilaian. Data efektivitas diperoleh dari lembar tes kompetensi kognitif peserta didik, lembar observasi kompetensi afektif peserta didik dan lembar observasi kompetensi psikomotor peserta didik. Hasil penelitian menunjukkan bahwa perangkat pembelajaran matematika yang dikembangkan telah valid, praktis dan efektif. Pada jurnal ini hanya dibahas peningkatan pemahaman konsep dan kemampuan penalaran matematika peserta didik setelah digunakan perangkat pembelajaran matematika berbasis discovery learning.
\end{abstract}

Kata kunci: Discovery Learning, Pemahaman Konsep dan Kemampuan Penalaran Matematika.

\section{Abstract}

Understanding the concepts and math reasoning ability of learners in schools has not developed optimally. This is because, teachers have not facilitate learners to be active in learning. In other words, learning done in schools has not been meaningful learning. One of the causes of mathematics learning tools used by educators has not supported the achievement of optimal learning objectives. The purpose of this research is to produce as learning device based on discovery learning mathematics on equation material and linear inequality that is valid, practical, and effective. This research is a development research using the Plomp development model consisting of initial investigation phase, prototype development or prototype phase, and assessment phase. The effectiveness data is obtained from the cognitive competence test sheet of the learner, observation sheet of students' affective competence and observation sheet of psychomotor competence of the learner. The results showed that the learning tools of mathematics developed were valid, practical and effective. In this journal only discussed increased understanding of the concept and the ability of mathematical reasoning of learners after use of learning devices based on discovery learning mathematics.

Keywords: Discovery Learning, Conceptual Understanding and Reasoning Math Abilities.

Peer review under responsibility UIN Imam Bonjol Padang.

(C) 2018 UIN Imam Bonjol Padang. All rights reserved. 


\section{PENDAHULUAN}

Matematika disebut juga sebagai ratu ilmu. Artinya matematika membantu ilmu-ilmu lain dalam operasional kerja yang dilakukan. Contoh saja dalam bidang biologi, meteorologi, asuransi, operasi-operasi bisnis, dan berbagai bidang eksperimen lainnya tidak akan pernah terlepas dari matematika. Seorang biologiwan menggunakan konsep matematika dalam persilangan genetik, seorang meteorologi menggunakan matematika dalam menentukan curah hujan serta dalam menentukan asuransi paling banyak digunakan matematika. Jadi jelas matematika sangatlah penting dalam kehidupan.

Jika dilihat bagaimana refleksi kemampuan matematika secara umum di kaca internasional. Berdasarkan Program For International Student Assesment (PISA) di bawah Organization Economic Cooperation and Development pada tahun 2012 mengadakan survei tentang kemampuan peserta didik dan sistem pendidikan. Survei ini melibatkan 510 ribu pelajar berusia 1516 tahun dari 65 negara dunia yang mewakili populasi 28 juta peserta didik berusia 15-16 tahun di dunia serta $80 \%$ ekonomi global. Hasil yang diperoleh Shanghai kota di China berpendudukan 23 juta orang menduduki peringkat pertama dalam survey PISA 2012. Sedangkan Indonesia menduduki peringkat 64 dari 65 negara, dengan kata lain kedua terendah sebelum Peru. Jadi jelas kemampuan matematika di Negara Indonesia belum berkembang sebagaimana mestinya.

Berbicara tentang matematika, matematika sering disebut sebagai ilmu pasti dan asbtrak, karena ilmu pasti banyak peserta didik yang menyenanginya. Sedangkan akibat dari abstraknya matematika, banyak peserta didik yang tidak menyenangi pelajaran ini. Banyaknya peserta didik yang tidak menyenangi matematika juga disebabkan oleh proses pembelajaran yang tidak menyenangkan, sarana, dan prasarana dalam pembelajaran matematika yang belum memuaskan. Selain itu penilaian yang dilakukan guru juga belum menggunakan pedoman penskoran yang benar. Berikut contoh penilaian yang digunakan guru.

\section{J. Instrumen Penilaian Hasil belajar \\ 1. Tentukan Himpunan penyelesaian dari sistem persamaan linear berikut!

$$
\begin{aligned}
& \begin{array}{ll}
\text { a. } 3 x+y=-1 & \text { b. }-6 x+4 y=10
\end{array} \\
& x-y=-3 \quad 3 x-2 y=-5
\end{aligned}
$$ \\ Keterangan Rubrik Penilaian \\ A. Pemahaman apa yang diketahul dan apa yang ditanya \\ 1. Jika Sama Sekali tidak memahami \\ 2. Tika Pemahamannya sebagian kecil \\ 3. Jikapemahamannya sebagian besar \\ 4. fikasangat memahaml}

Gambar 1. Contoh Penilaian

Penilaian yang terlihat pada Gambar 1, hanya menilai kemampuan kognitif saja. Rubrik yang digunakan juga belum benar. Contohnya skala 2 jika pemahamannya sebagian kecil, ini kurang jelas seperti apa jawaban peserta didik yang penilaiannya skala 2 maupun yang lainnya. Penilaian seperti ini belum sesuai dengan kurikulum 2013 yang memuat ketiga aspek dan rubrik penskoran yang benar.

Selain itu ditemukan hasil dari ulangan harian I yang belum optimal. Dari seluruh peserta didik yang mengikuti ulangan harian I dengan materi eksponen dan logaritma. Soal ulangan harian berisikan $50 \%$ soal penalaran yang memiliki tingkat kesulitan, ketelitian yang tinggi dan $50 \%$ soal pemahaman konsep. Hasil yang diperoleh lebih banyak peserta didik yang tidak 
tuntas atau nilainya dibawah KKM dari pada peserta didik yang tuntas atau nilainya diatas KKM dengan KKM adalah 80.

Hasil ulangan harian menunjukkan tujuan pembelajaran matematika belum tercapai pada materi eksponen dan logaritma. Soal yang diberikan hanya berisikan soal pemahaman konsep dan penalaran, maka dapat disimpulkan pemahaman konsep peserta didik masih rendah karena peserta didik banyak yang tidak tuntas. Tujuan pembelajaran matematika saling berhubungan satu sama lain apabila pemahaman konsep peserta didik yang masih rendah maka tujuan pembelajaran matematika selanjutnya yaitu penalaran, komunikasi, pemecahan masalah dan lain-lain juga belum tercapai. Salah satu penyebabnya pada saat pemberian latihan, soalsoal latihan yang sering diberikan guru agak mirip dengan contoh yaitu soal-soal yang berisikan tentang pemahaman konsep selain dari itu peserta didik juga tidak terbiasa menemukan konsep dari materi. Akibatnya ketika guru memberikan soalsoal ulangan yang membutuhkan penalaran yang agak berbeda dengan soal rutin, maka peserta didik akan kebingungan dalam menyelesaikannya.

Materi persamaan dan pertidaksamaan linear merupakan materi yang sangat penting dan materi yang dipelajari setelah eksponen dan logaritma. Materi ini selalu menjadi materi prasyarat untuk jenjang selanjutnya, contoh lingkaran di kelas XI dan program linear di kelas XII. Pada materi ini peserta didik sering tidak memahami kenapa dari huruf $\mathrm{x}, \mathrm{y}$, dan $\mathrm{z}$ bisa berubah menjadi angka. Selain itu, guru jarang menjelaskan kegunaan materi ini dan hubungannya dengan kehidupan sehari-hari. Guru selalu memberikan bentuk umum, rumus-rumus dan contoh soal, sehingga materi ini menjadi materi yang membosankan bagi peserta didik. Berikut Tabel yang menunjukkan rendahnya hasil belajar peserta didik yang diambil dari salah satu sekolah yang diobservasi yaitu SMAN 2 PAINAN.

Tabel 1. Persentase Ketuntasan Hasil Belajar Peserta Didik pada Ulangan Harian II Semester I Mata Pelajaran Matematika Peserta didik Kelas X IPA SMAN 2 Painan

\begin{tabular}{|c|c|c|c|c|c|}
\hline \multirow[b]{2}{*}{ Kelas } & \multirow[b]{2}{*}{$\begin{array}{c}\text { Jumlah } \\
\text { peserta } \\
\text { didik }\end{array}$} & \multicolumn{2}{|c|}{ Persentase nilai $\geq 80$} & \multicolumn{2}{|c|}{ Persentase nilai $<80$} \\
\hline & & $\begin{array}{c}\text { Jumlah } \\
\text { peserta } \\
\text { didik }\end{array}$ & Persentase & $\begin{array}{c}\text { Jumlah } \\
\text { peserta } \\
\text { didik }\end{array}$ & Persentase \\
\hline $\mathrm{X} \mathrm{IPA}_{1}$ & 28 & 8 & 28,57 & 20 & 71,43 \\
\hline $\mathrm{X} \mathrm{IPA}{ }_{2}$ & 25 & 17 & 68,00 & 8 & 32,00 \\
\hline $\mathrm{X} \mathrm{IPA}{ }_{3}$ & 25 & 8 & 32,00 & 17 & 68,00 \\
\hline $\mathrm{X} \mathrm{IPA}_{4}$ & 27 & 9 & 33,33 & 18 & 66,67 \\
\hline $\mathrm{X} \mathrm{IPA}_{5}$ & 26 & 9 & 34,62 & 17 & 65,38 \\
\hline $\mathrm{X} \mathrm{IPA}_{6}$ & 29 & 18 & 62,07 & 11 & 37,93 \\
\hline
\end{tabular}

(Sumber : Guru mata pelajaran Matematika SMAN 2 Painan)

Rendahnya hasil belajar peserta didik juga terlihat dari aktivitas peserta didik pada pembelajaran matematika yang masih rendah. Pada saat pembelajaran berlangsung, ditemukan peserta didik mengerjakan aktivitas lain seperti buat tugas yang bukan matematika. Ketika guru meminta peserta didik untuk memperhatikan, ada peserta didik yang terlihat mengantuk dan ngobrol dengan teman. Guru juga telah berusaha mengarahkan agar peserta didik membaca, mencoba latihan yang diberikan guru akan tetapi masih banyak peserta didik yang tidak mencoba atau tetap diam. Jadi pembelajaran belum terlaksana secara optimal.

Berdasarkan hasil wawancara dengan beberapa peserta didik, mengungkapkan malas ketika belajar matematika karena pembelajarannya 
membosankan. Banyak latihan di LKPD yang membuat bosan dan malas untuk dikerjakan. Selain itu, peserta didik juga mengungkapkan bahwa pembelajaran matematika banyak rumus yang harus dihafal dan tidak ada hubungannya dengan kehidupan sehari-hari.

Jika kondisi ini terus dibiarkan maka peserta didik akan beranggapan pembelajaran matematika pembelajaran yang paling sulit. Peserta didik tidak menyukai pembelajaran matematika dan malas jika berhubungan dengan pembelajaran matematika. Peserta didik akan kalah saing baik dalam dunia pendidikan, maupun dalam kehidupan sehari-hari. Sejalan dengan itu, jika peserta didik tidak mampu menggunakan penalaran tentunya peserta didik tidak bisa mengikuti perkembangan zaman yang membutuhkan pola pikir yang tinggi.

Untuk mengantisipasi masalah ini yaitu belum optimalnya pengembangan perangkat pembelajaran matematika pada kurikulum 2013 yang mengakibatkan rendahnya pemahaman konsep dan kemampuan penalaran matematika. Guru matematika bertanggung jawab membuat peserta didik tertarik dan merubah pola belajar yang cendrung menerima lebih aktif dalam belajar sehingga peserta didik dapat menggunakan pola pikirnya. Pendekatan saintifik dianjurkan pada kurikulum 2013 dengan menggunakan beberapa model diantaranya problem base learning, discovery learning, dan project base learning. Pembelajaran yang diharapkan bisa menfasilitasi peserta didik menggunakan pola pikirnya. Peneliti tertarik untuk mencoba mengembangkan perangkat pembelajaran matematika berbasis discovery learning untuk materi persamaan dan pertidaksamaan linear di kelas X SMA.

Pada discovery learning peserta didik dituntun untuk menemukan konsep pembelajaran yang sebelumnya tidak diketahui. Peserta didik terlibat aktif dalam pembelajaran karena peserta didik harus menggunakan seluruh pemikiran dan keterampilan yang dimiliki untuk menemukan konsep pembelajaran. Dalam discovery learning materi atau bahan pelajaran yang akan diberikan tidak dalam bentuk final. Akan tetapi peserta didik didorong untuk mengidentifikasi apa yang ingin diketahui dilanjutkan dengan mencari informasi sendiri kemudian mengorgansasi atau membentuk (konstruktif) apa yang mereka ketahui dan mereka pahami dalam suatu bentuk akhir.

Perangkat pembelajaran berbasis discovery learning untuk materi persamaan dan pertidaksamaan linear pada kelas X SMA memiliki beberapa tahapan yaitu pemberian rangsangan, mengidentifikasi masalah, mengumpulkan data, mengolah data, pembuktian dan menarik kesimpulan dalam (Hosnan, 2014: 289). Dengan tahapan tersebut diharapkan menfasilitasi peserta didik selama dan setelah pembelajaran berlangsung. Pembelajaran ini menuntut peserta didik untuk menemukan sendiri konsep dari materi yang akan dipelajari. Dengan kata lain perangkat yang akan dikembangkan akan menciptakan pembelajaran bermakna.

Pada tahapan pemberian rangsangan dan mengidentifikasi masalah diharapkan peserta didik memahami kegunaan materi persamaan dan pertidaksamaan linear dalam kehidupan seharihari. Pada tahapan mengumpulkan data dan mengolah data diharapkan peserta didik bisa 
menemukan konsep dari materi sehingga pemahaman konsep peserta didik berkembang. Pada tahapan pembuktian dan menarik kesimpulan diharapkan pemahaman konsep peserta didik semakin meningkat sehingga dapat menggunakan kemampuan penalarannya. Peneliti menduga dengan perangkat pembelajaran seperti ini materi yang dipelajari peserta didik akan bertahan lama dalam ingatannya atau dengan kata lain pembelajaran yang dilakukan bermakna. Dengan belajar bermakna, peserta didik akan menyenangi pembelajaran matematika dan memiliki ketertarikan dengan masalah-masalah yang diberikan.

Petunjuk teknis peraturan Dirjen Dikdasmen Depdiknas tentang penilaian perkembangan anak didik (Wardhani, 2008) mengemukakan bahwa indikator yang menunjukan pemahaman konsep antara lain:

a. Menyatakan ulang sebuah konsep

b. Mengklasifikasikan objek menurut sifatsifat tertentu (sesuai dengan konsepnya)

c. Memberi contoh dan bukan contoh dari konsep

d. Menyajikan konsep dalam berbagai bentuk representasi matematis

e. Mengembangkan syarat perlu dan syarat cukup suatu konsep

f. Menggunakan, memanfaatkan dan memilih prosedur atau operasi tertentu

g. Mengaplikasikan konsep atau algoritma pemecahan masalah

Indikator pemahaman konsep yang diukur dalam penelitian ini adalah (a) menyatakan ulang sebuah konsep, (b) Mengklasifikasikan objek menurut sifat-sifat tertentu (sesuai dengan konsepnya), dan (c) Menggunakan, memanfaatkan dan memilih prosedur atau operasi tertentu.

Peraturan

Dirjen

Dikdasmen

No.506/C/PP/2004 (Wardhani, 2008) tentang indikator-indikator penalaran yang harus dicapai peserta didik. Indikator yang menunjukkan penalaran antara lain adalah:

a. Kemampuan menyajikan pernyataan matematika secara lisan, tertulis, gambar dan diagram.

b. Kemampuan mengajukan dugaan.

c. Kemampuan melakukan manipulasi matematika.

d. Kemampuan menyusun bukti, memberikan alasan /bukti terhadap kebenaran solusi.

e. Kemamapuan menarik kesimpulan dari pernyataan.

f. Memeriksa kesahihan suatu argument.

g. Menemukan pola atau sifat dari gejala matematis untuk membuat generalisasi.

Dari ketujuh indikator tersebut diharapkan tercapai dan bagus di sekolah-sekolah, akan tetapi pada umumnya masih banyak yang rendah, ini disebabkan karena pembelajaran yang digunakan masih pembelajaran konvensional sehingga kemampuan penalaran peserta didik belum terlalu berkembang. Berdasarkan cakupan materi pada penelitian yaitu persamaan lingkaran dan persamaan garis singgung lingkaran melalui sebuah titik dan lebih terfokusnya penelitian yang dilaksanakan maka hanya digunakan 4 indikator yaitu indikator a, c, d, dan e. Penilaian pada kuis dan tes akhir menggunakan rubrik analitik. Menurut (Iryanti, 2004:13) Rubrik analitik adalah pedoman untuk menilai berdasarkan beberapa 
kriteria yang ditentukan. Dengan menggunakan rubrik ini dapat dianalisa kelemahan dan kelebihan seorang siswa terletak pada kriteria yang mana. Jadi kita dapat mengetahui di indikator penalaran yang mana siswa yang banyak rendah, sehingga dapat dijadikan evaluasi bagi guru.

\section{METODE PENELITIAN}

Penelitian ini merupakan penelitian pengembangan menggunakan model Plomp dengan tiga tahapan. Tahapan pertama merupakan fase investigasi awal dengan melakukan analisis kebutuhan, analisis kurikulum, analisis konsep, dan analisis peserta didik. Tahapan kedua yaitu fase pembuatan prototipe dengan dilakukan perancangan perangkat pembelajaran matematika berbasis discovery learning pada materi persamaan dan pertidaksamaan linear. Kemudian dilanjutkan dengan evaluasi sendiri oleh peneliti dan dua teman sejawat. Hasil analisis dan revisi berdasarkan evaluasi sendiri dilanjutkan dengan validasi oleh lima validator. Setelah direvisi berdasarkan saran validator dan perangkat pembelajaran dinyatakan valid kemudian dilanjutkan dengan evaluasi satu-satu (Plomp, 2013).

Evaluasi satu-satu dilakukan oleh tiga orang peserta didik dengan kemampuan rendah, sedang, dan tinggi. Pada evaluasi satu-satu dilihat kesalahan penulisan. Kemudian dilanjutkan dengan evaluasi kelompok kecil oleh tujuh orang peserta didik. Pada tahap ini dilihat praktikalitas perangkat pembelajaran matematika pada skala kecil. Hasil analisis evaluasi kelompok kecil diujicobakan pada kelompok besar yaitu SMAN 2 Painan yang merupakan tahapan ketiga. Pada tahap ini dilakukan uji praktikalitas dan uji efektivitas.

Instrumen pengumpulan data meliputi isntrumen fase investigasi awal berupa lembar analisis kebutuhan, kurikulum, peserta didik dan konsep, lembar observasi dan pedoman wawancara. Instrumen kevalidan meliputi instrumen self evaluation, instrumen validasi. Instrumen kepraktisan melalui angket peserta didik, angket guru, lembar keterlaksanaan RPP dan lembar keterlaksanaan penilaian. Instrumen keefektivan melalui tes kognitif berupa kuis dan tes akhir, tes afektif berupa lembar pengamatan sikap, dan tes psikomotor berupa lembar pengamatan keterampilan. Setiap instrumen yang digunakan pada penelitian ini divalidasi terlebih dahulu. Setelah seluruh intrumen dinyatakan valid oleh tiga validator kemudian digunakan dalam penelitian.

Data praktikalitas diperoleh dari hasil wawancara dengan peserta didik, angket praktikalitas yang diisi peserta didik dan angket praktikalitas yang diisi oleh guru. Guru yang mengisi lembar praktilitas terdiri atas 2 orang yaitu guru matematika SMAN 2 Painan, serta 36 peserta didik dari kelas XI MIA 4 SMAN 2 Painan.

Data efektivitas diperoleh dari penilaian kompetensi kognitif, berupak kuis dan tes akhir. Penilaian afektif berupa lembar pengamatan kompetensi sikap yang dinilai setiap pertemuan. Penilaian psikomotor berupa lembar pengamatan kompetensi keterampilan yang dinilai juga disetiap pertemuan. 


\section{Jenis Penelitian}

Penelitian ini dirancang dengan menggunakan penelitian pengembangan dengan model Plomp. Pada pengembangan yang dilakukan menggunakan tiga tahapan pada model Plomp. Tahapan-tahapan yang dilakukan meliputi fase investigasi awal, fase pengembangan atau pembuatan prototipe, dan fase penilaian.

\section{Waktu dan Tempat Penelitian}

Perancangan dan pengembangan dilakukan dari Juli s.d Agustus 2015, sedangkan fase penilaian dilakukan dari tanggal 18 Aagustus 2015 s.d 18 Oktober 2015. Dalam penelitian ini, fase penilaian dilakukan di SMAN 2 Painan.

\section{Subjek Penelitian}

Dalam penelitian ini, fase penilaian yang menjadi subjek uji coba yaitu guru dan peserta didik. Guru dan peserta didik yang menggunakan perangkat pembelajaran ini yang sekaligus diamati yaitu pada kelas X MIA 4 SMAN 2 Painan.

\section{Prosedur}

Tahapan yang digunakan menggunakan model pengembangan Plomp .Tahapan pertama merupakan fase investigasi awal dengan melakukan analisis kebutuhan, analisis kurikulum, analisis konsep, dan analisis peserta didik. Tahapan kedua yaitu fase pembuatan prototipe dengan dilakukan perancangan perangkat pembelajaran matematika berbasis discovery learning pada materi persamaan dan pertidaksamaan linear. Kemudian dilanjutkan dengan evaluasi sendiri oleh peneliti dan dua teman sejawat. Hasil analisis dan revisi berdasarkan evaluasi sendiri dilanjutkan dengan validasi oleh lima validator. Setelah direvisi berdasarkan saran validator dan perangkat pembelajaran dinyatakan valid kemudian dilanjutkan dengan evaluasi satu-satu. Evaluasi satu-satu dilakukan oleh tiga orang peserta didik dengan kemampuan rendah, sedang, dan tinggi. Kemudian dilanjutkan dengan evaluasi kelompok kecil oleh tujuh orang peserta didik. Pada tahap ini dilihat praktikalitas perangkat pembelajaran matematika pada skala kecil.

Hasil analisis evaluasi kelompok kecil diujicobakan pada kelompok besar yaitu SMAN 2 Painan yang merupakan tahapan ketiga. Pada tahap ini dilakukan uji praktikalitas dan uji efektivitas. Pada tahap ujicoba kelompok besar yang digunakan soal pemahaman konsep dan kemampuan penalaran matematika peserta didik yang diberikan kuis di setiap pertemuan dan tes akhir.

Data, Intrumen, dan Teknik Pengumpulan Data

Jenis data yang digunakan untuk mengetahui peningkatan pemahaman konsep dan kemampuan penalaran matematika peserta didik adalah data kuantitatif . data kuantitatif diperoleh dengan memberikan kuis di setiap pertemuan dan tes akhir di akhir materi persamaan dan pertidaksamaan linear.

\section{Teknik Analisis Data}

Ketuntasan belajar untuk pengetahuan ditetapkan dengan skor rerata 2,67 dalam permendikbud nomor 104 tahun 2014 . Pembelajaran yang menerapkan perangkat pembelajaran matematika yang dikembangkan dikatakan efektif apabila memperoleh ketuntasan belajar minimal dengan skor rerata 2.67 dan 
ketuntasan klasikal dan individual lebih besar atau sama dengan $80 \%$. Untuk menghitung ketuntasan individual dapat dilakukan dengan menggunakan rumus (dalam Trianto, 2010) sebagai berikut.

$$
K I=\frac{\text { jumlah skor pesertadidik }}{\text { jumlah skortotal }} \times 100 \%
$$

Sedangkan untuk menghitung ketuntasan klasikal dapat dilakukan dengan menggunakan rumus sebagai berikut.

$$
K K=\frac{j u m l a h \text { peserta didikyang lulus KKM }}{\text { jumlah seluruh peserta didik }} \times 100 \%
$$

Peningkatan pemahaman konsep dan kemampuan penalaran matematika peserta didik dianalisis dengan melihat penigkatan kriteria ketuntasan minimal di setiap pertemuan melalui kuis yang diberikan. Hasil tes akhir dibandingkan dengan data awal yang diperoleh pada penelitian ini.

\section{HASIL DAN PEMBAHASAN}

Peningkatan pemahaman konsep dan kemampuan penalaran matematika peserta didik di lihat melalui kuis di setiap pertemuan dan tes akhir setelah materi persamaan dan pertidaksamaan linear dipelajari. Rincian rata-rata kuis dan tes akhir terlihat pada Tabel 2. Dari 35 orang peserta didik diantaranya 30 orang lulus KKM dan 5 orang tidak lulus KKM. Berdasarkan hasil tes akhir diperoleh 82,91\% ketuntasan individual dan $85,71 \%$ ketuntasan klasikal. Peserta didik mendapatkan prediket $\mathrm{C}^{+}(2,86 \%)$, prediket $\mathrm{B}^{-}$ $(2,86 \%)$, prediket $\mathrm{B}(8,57 \%)$, prediket $\mathrm{B}^{+}$ $(57,14 \%)$, prediket $\mathrm{A}^{-}(17,14 \%)$, dan A $(2,86 \%)$. Hal ini menunjukkan bahwa dengan penggunaan perangkat pembelajaran matematika berbasis discovery learning untuk materi persamaan linear dan pertidaksamaan linear terjadi peningkatan dibandingkan kondisi awal pada Tabel 1.

Tabel 2. Rata-rata kuis dan tes akhir

\begin{tabular}{ccc}
\hline Pertemuan & $\begin{array}{c}\text { Rata-rata } \\
\text { Nilai Kuis }\end{array}$ & $\begin{array}{c}\text { Rata-rata } \\
\text { Nilai Tes Akhir }\end{array}$ \\
\hline I & 3.34 & \\
II & 3.16 & 3.32 \\
III & 3.28 & \\
IV & 3.40 & \\
\hline
\end{tabular}

Pada pertemuan I dan II, soal kuis berisikan soal pemahaman konsep peserta didik. Dari hasil kuis kedua pertemuan terlihat bahwa terdapat peningkatan pemahaman konsep peserta didik. Sebelum menggunakan perangkat pembelajaran discovery learning, dalam menjawab kuis peserta didik banyak yang salah karena mereka membuat jawaban langsung tanpa memahami dengan benar terlebih dahulu informasi yang ada pada soal. Jawaban salah satu kuis peserta didik terlihat pada Gambar 2.

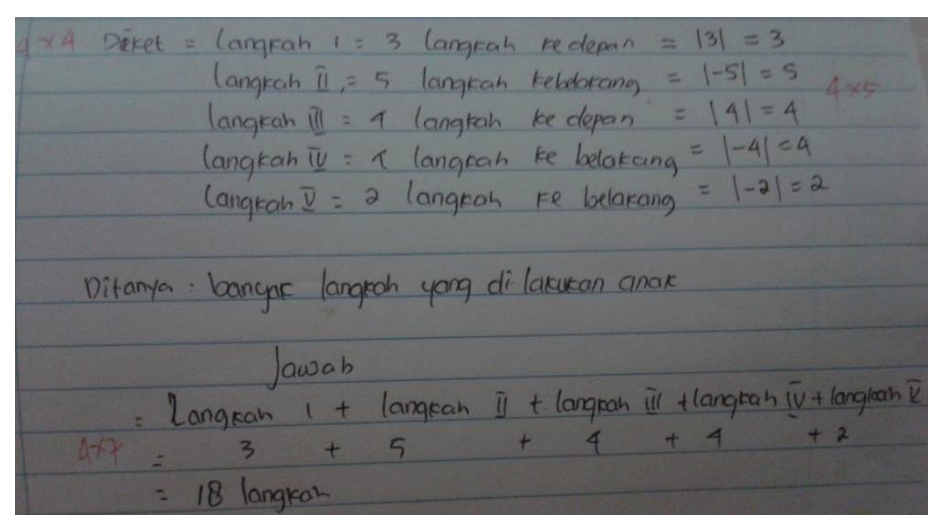

Gambar 2. Jawaban Kuis Pertemuan I

Berdasarkan Gambar 2 merupakan jawaban soal pemahaman konsep yang terdiri atas indikator menyatakan ulang sebuah konsep, mengklasifikasikan objek menurut sifat-sifat tertentu (sesuai dengan konsepnya), dan menggunakan, memanfaatkan dan memilih 
prosedur atau operasi tertentu dalm Depdiknas (2004:58). Dari ketiga indikator yang diukur terlihat peserta didik memperoleh skala 4. Artinya peserta didik telah mampu menggunakan pemahaman konsep secara maksimal pada indikator tersebut. Dari seluruh peserta didik yang mengikuti kuis, sebagian besar peserta didik telah memperoleh skala 3 dan 4 untuk ketiga indikator tesebut. Hal ini juga di peroleh pada pertemuan II.

Pada pertemuan III dan IV, soal kuis berisikan kemampuan penalaran matematika peserta didik. Dari hasil kuis kedua pertemuan terlihat bahwa terdapat peningkatan kemampuan penalaran matematika peserta didik. Sebelum menggunakan perangkat pembelajaran discovery learning, jika diberikan soal penalaran maka peserta didik kesulitan dalam menyelesaikannya. Hal ini disebabkan peserta didik tidak terbiasa menggunakan penalarannya. Jawaban kuis peserta didik pertemuan IV terlihat pada Gambar 2.

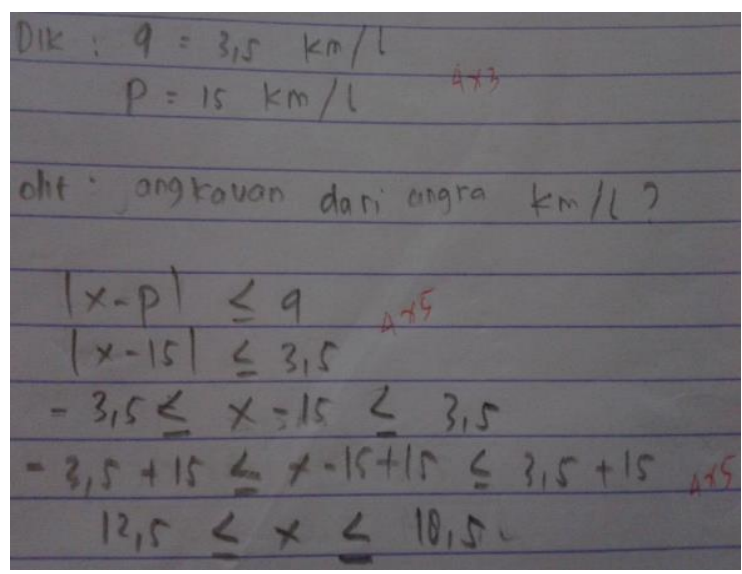

Gambar 3. Jawaban Kuis Pertemuan IV

Gambar 3 merupakan jawaban soal kemampuan penalaran matematika yang terdiri atas indikator menyajikan pernyataan matematika secara tertulis dan gambar, melakukan manipulasi matematika, kemampuan menyusun bukti, memberikan alasan/ bukti terhadap kebenaran solusi dan menarik Kesimpulan dari pernyataan. Dari keempat indikator yang diukur terlihat peserta didik memperoleh skala 4. Artinya peserta didik telah mampu menggunakan penalaran matematika secara maksimal pada indikator tersebut. Dari seluruh peserta didik yang mengikuti kuis, sebagian besar peserta didik telah memperoleh skala 3 dan 4 untuk ketiga indikator tesebut. Hal ini juga di peroleh pada pertemuan III.
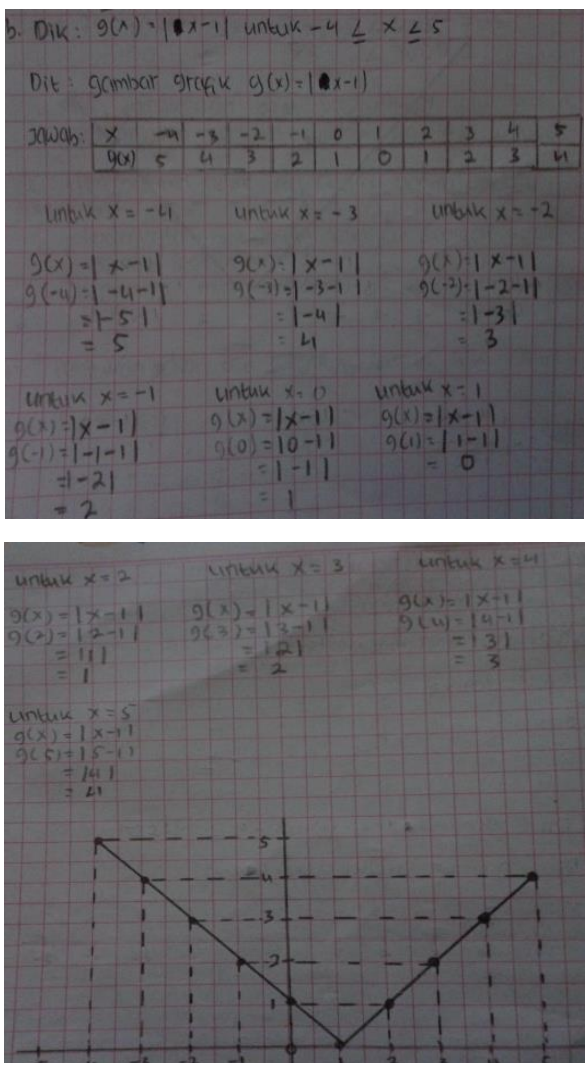

Gambar 4 . Jawaban Ulangan Harian Nomor 1

Soal nomor 1 pada Gambar 4 merupakan soal pemahaman konsep. Dari hasil ulangan harian peserta didik diperoleh sebagian besar peserta didik memperoleh skala 3 dan 4. Artinya sebagian besar peserta didik telah memiliki pemahaman konsep yang baik. Soal tes akhir terdiri atas 4 buah, 2 soal pemahaman konsep dan 2 soal penalaran. Soal nomor 1 dan 2 soal pemahaman konsep. Soal 3 dan 4 merupakan soal penalaran. Gambar 5 merupakan jawaban ulangan harian nomor 3. Dari Gambar nomor 5 terlihat bahwa 
peserta didik memperoleh skala 4. Artinya peserta didik memiliki kemampuan penalaran matematika yang bagus. Hal ini juga diperoleh dari sebagian besar peserta didik yang mengikuti ulangan harian.

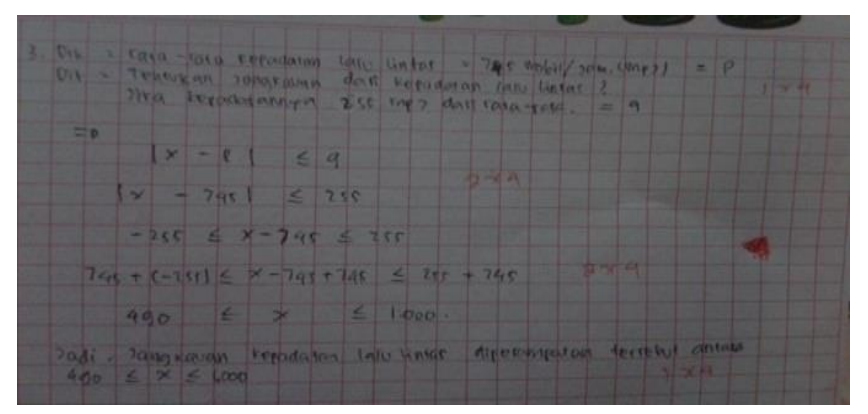

Gambar 5. Jawaban Ulangan Harian Nomor 3

Hasil belajar kompetensi kognitif diperoleh melalui kuis di setiap pertemuan dan tes akhir setelah materi persamaan dan pertidaksamaan linear selesai. Pada pertemuan I sampai IV diperoleh rata-rata kuis 3.34, 3.16, 3.28 dan 3.40. Terlihat bahwa rata-rata ketuntasan kuis di setiap pertemuan > 2,67 yaitu rata-rata yang ditetapkan dalam Permendikbud nomor 104 tahun 2014. Artinya terdapat peningkatan pemahaman konsep dan kemampuan penalaran matematika peserta didik dengan digunakan perangkat pembelajaran matematika berbasis discovery learning.

Pada kuis I dari 36 peserta didik yang hadir hanya 34 orang dengan 2 orang sakit. Diperoleh 27 orang peserta didik mencapai KKM dan 7 orang berada di bawah KKM. Dari 34 peserta didik yang mengikuti kuis diperoleh 9 orang peserta didik dengan predikat $\mathrm{A}^{-}, 18$ orang dengan pridekat $\mathrm{B}^{+}, 6$ orang dengan predikat $\mathrm{B}$ dan 1 orang dengan predikat $\mathrm{B}^{-}$. Hal ini menunjukkan bahwa pada pertemuan I nilai peserta didik didominasi dengan $\mathrm{B}^{+}$dan peserta didik yang mencapai ketuntasan yang ditetapkan Permendikbud nomor 104 tahun 2014 sebesar
97,00 \% dan ketuntasan yang ditetapkan sekolah $79,00 \%$. Soal kuis berisikan soal pemahaman konsep. Jadi terjadi perekembangan pemahaman konsep matematika peserta didik.

Pada kuis II dari 36 peserta didik yang hadir hanya 35 orang dengan 1 orang sakit. Diperoleh 25 orang peserta didik mencapai KKM dan 10 orang berada di bawah KKM. Dari 35 peserta didik yang mengikuti kuis diperoleh 5 orang peserta didik dengan predikat $\mathrm{A}^{-}, 20$ orang dengan pridekat $\mathrm{B}^{+}, 4$ orang dengan predikat $\mathrm{B}, 3$ orang lengan predikat $\mathrm{B}^{-}, 2$ orang dengan prediket $\mathrm{C}^{+}$ dan 1 orang dengan prediket $C$. Hal ini menunjukkan bahwa pada pertemuan II nilai peserta didik juga didominasi dengan $\mathrm{B}^{+}$dan peserta didik yang mencapai ketuntasan yang ditetapkan Permendikbud nomor 104 tahun 2014 sebesar 83,00 \% dan ketuntasan yang ditetapkan sekolah 74,00 \%. Soal kuis pertemuan II juga berisikan soal pemahaman konsep. Dapat disimpulkan dari hasil pertemuan kuis I dan kuis II pemahaman konsep peserta didik meningkat dengan baik.

Pada kuis III dari 36 peserta didik yang hadir hanya 35 orang dengan 1 orang izin. Diperoleh 27 orang peserta didik mencapai KKM dan 8 orang berada di bawah KKM. Dari 35 peserta didik yang mengikuti kuis diperoleh 1 orang peserta didik dengan prediket $A, 10$ orang dengan predikat $\mathrm{A}^{-}, 16$ orang dengan pridekat $\mathrm{B}^{+}$, 3 orang dengan predikat $\mathrm{B}$ dan 5 orang dengan predikat $\mathrm{B}^{-}$. Hal ini menunjukkan bahwa pada pertemuan III nilai peserta didik didominasi dengan $\mathrm{B}^{+}$dan peserta didik yang mencapai ketuntasan yang ditetapkan Permendikbud nomor 104 tahun 2014 sebesar 91,00 \% dan ketuntasan 
yang ditetapkan sekolah $77,00 \%$. Soal kuis berisikan soal kemampuan penalaran matematis peserta didik. Dapat disimpulkan dari hasil pertemuan kuis III terjadi perkembangan kemampuan penalaran matematis peserta didik peserta didik.

Pada kuis IV diikuti oleh 36 orang peserta didik. Diperoleh 31 orang peserta didik mencapai KKM dan 5 orang berada di bawah KKM. Dari 36 peserta didik yang mengikuti kuis diperoleh 4 orang peserta didik dengan prediket A, 10 orang dengan predikat $\mathrm{A}^{-}, 17$ orang dengan pridekat $\mathrm{B}^{+}$, 4 orang dengan predikat $\mathrm{B}$ dan 1 orang dengan predikat $\mathrm{B}^{-}$. Hal ini menunjukkan bahwa pada pertemuan IV nilai peserta didik didominasi dengan $\mathrm{B}^{+}$dan peserta didik yang mencapai ketuntasan yang ditetapkan permendikbud nomor 104 tahun 2014 sebesar 97,00 \% dan ketuntasan yang ditetapkan sekolah $86,00 \%$. Dapat disimpulkan dari hasil pertemuan kuis III dan kuis IV yang berisikan soal kemampuan penalaran matematis peserta didik, terjadi peningkatan yang lebih baik.

Berdasarkan hasil tes akhir peserta didik kelas X MIA 4 SMAN 2 Painan diperoleh nilai rata-rata 3.32 dengan $82,91 \%$ ketuntasan individual dan $85,71 \%$ ketuntasan klasikal. Nilai rata-rata kelas yang diperoleh berada di atas KKM. Dari hasil analisis ulangan harian, diketahui bahwa 30 orang dari 35 orang peserta didik yang mendapat nilai diatas KKM yang didominasi oleh predikat $\mathrm{B}^{+}$sebesar $57.14 \%$. Peserta didik mendapatkan prediket $\mathrm{C}^{+}(2,86 \%)$, prediket $\mathrm{B}^{-}$ $(2,86 \%)$, prediket $\mathrm{B}(8,57 \%)$, prediket $\mathrm{A}^{-}(17,14$ $\%)$, dan prediket A $(2,86 \%)$. Hal ini menunjukkan bahwa perangkat pembelajaran matematika berbasis discovery learning berhasil membantu peserta didik untuk memahami konsep dan mengembankan kemampuan penalaran matematika peserta didik pada materi persamaan dan pertidaksamaan linear.

\section{SIMPULAN DAN SARAN}

Adapun simpulan dari penelitian ini dan saran bagi peneliti selanjutnya adalah sebagai berikut:

\section{Simpulan}

1. Terjadi peningkatan pemahaman konsep peserta didik setelah diterapkan perangkat pembelajaran matematika berbasis discovery learning pada materi persamaan dan pertidaksamaan linear untuk kelas X SMA.

2. Terjadi peningkatan kemampuan penalaran matematika peserta didik setelah diterapkan perangkat pembelajaran matematika berbasis discovery learning pada materi persamaan dan pertidaksamaan linear untuk kelas $\mathrm{X}$ SMA.

\section{Saran}

1. Perangkat pembelajaran matematika berbasis discovery learning untuk materi persamaan dan pertidaksamaan linear pada Sekolah Menengah Atas (SMA) yang dikembangkan ini telah dinyatakan valid, praktis, dan efektif dan dapat meningkatkan pemahaman konsep serta kemampuan penalaran matematika peserta didik sehingga disarankan untuk dapat digunakan oleh guru matematika sebagai alternatif bahan ajar 
dalam pembelajaran materi persamaan dan pertidaksamaan linear kelas X.

2. Perlu dilakukan uji coba terbatas di sekolah lain agar lebih diketahui bagaimana praktikalitas dan efektivitas perangkat pembelajaran matematika berbasis discovery learning yang dikembangkan

3. Bagi peneliti lain yang akan melanjutkan penelitian ini, disarankan untuk melakukan inovasi dalam penelitian berikutnya. Seperti pengembangan perangkat pembelajaran matematika untuk materi lain atau inovasi perangkat pembelajaran matematika yang baru

\section{DAFTAR PUSTAKA}

Hosnan. (2014). Pendekatan Saintifik Dan Kontekstual Dalam Pembelajaran Abad 21. Jakarta :Ghalia Indonesia.

Iryanti, Puji. (2004). Penilaian Untuk Kerja. Yogyakarta: Depdiknas.

Trianto. (2010). Model Pembelajaran Terpadu. Bumi Aksara : Jakarta.

Permendikbud nomor 104 tahun 2014

Plomp, T dan N. Nieveen. (2013). Educational Design Research. Enshede: Netherlands Institute For Curriculum Development (SLO).

Wardhani, Sri. (2008). Analisis SI dan SKL Mata Pelajaran Matematika SMP/MTs untuk Optimalisasi Tujuan Mata Pelajaran Matematika. Yogyakarta: Departemen Pendidikan

Nasional. 